\title{
Report on Incidence of Malvastrum coromandelianum to Vein Clearing Virus Disease (Malvastrum Yellow Vein Virus Disease) in Madurai
}

\author{
K. Kalaichelvi* \\ Agricultural College and Research Institute, Madurai, India \\ *Corresponding author
}

\section{A B S T R A C T}

\begin{tabular}{|l|}
\hline Ke y w o r d s \\
$\begin{array}{l}\text { Malvastrum } \\
\text { coromandelianum, } \\
\text { Sidaacuta, High } \\
\text { susceptibility to } \\
\text { vein clearing virus }\end{array}$ \\
\hline Article Info \\
$\begin{array}{l}\text { Accepted: } \\
\text { 25 October } 2020 \\
\text { Available Online: } \\
10 \text { November } 2020\end{array}$ \\
\hline
\end{tabular}

Under neem tree, weeds namely Sida acuta, Malvastrum coromendelianum, Ruellaprostrata, Commelina benghalensis, Abuitlon indicum, Hibiscus micranthus, Aervalanata, Acalypha indica, Leucas aspera, Physalis minima, Tribulus terestries and Mellingtonis hortensis (tree seedlings aged 2 years) are observed in Agricultural College and Research Institute, Madurai. Among these weeds, the severe infection of vein clearing is found in more number of plants of Malvastrum coromandelianum and Sida acuta. This Malvastrum being already reported with a specific virus (Malvastrum Yellow vein virus) reported in China. Sida acuta is highly susceptible for vein clearing and also leaf curl virus of tomato which was reported earlier. This infection is observed during October month in these volunteer plants continuously for the two years (2019 \& 2020). The population of the vector whitefly is also observed in the Malvastrum coromandelianum and Sida acuta, this may facilitate for the transmission of the virus and Eventhough, with vector population, these species alone being observed with infection with this specific virus remaining weeds are not infected hence this may be host specific. Hence Malvastrum coromandelianum is documented as highly susceptible to this specific virus and needs research on infecting to the crops.

\section{Introduction}

Weeds are reported to be the major carrier of virus over seasons and this has to be under surveillance for the transmission of the disease especially virus disease and this also the host for the vector also. Under neem tree, weeds namely Sida acuta, Malvastrum coromandelianum, Ruellaprostrata, Commelina benghalensis, Abuitlon indicum, Hibiscus micranthus, Aervalanata, Acalypha indica, Leucas aspera, Physalis minima, Tribulus terestries and Mellingtonis hortensis (tree seedlings aged 2 years) are observed in Agricultural College and Research Institute, Madurai. Among these weeds, the severe infection of vein clearing is found only in Malvastrum coromandelianum; the molecular data show that virus isolate Y47 is a distinct begomovirus species, for which the name Malvastrum yellow vein virus is proposed (Zhou Xueping et al., 2003)

Earlier reports showed that in Nigeria $S$. acuta and $S$. rhombifolia were able to be inoculated with Okra mosaic virus which belongs to the 
Tymoviridae family. In U.S.A, Sida golden mosaic Honduras virus (SiGMHV) (GenBank Accession No. Y11097 and Y11098), the second is the Sida yellow vein virus (SiYVV) (Accession No. Y11099 and Y11100) (Frischmuth et al., 1997) and the DNA-B has the Genbank Accession No. AJ250731 (Hfer et al., 1997) was documented. Recently, two DNA-A have been reported from Brazil from Sida spp. (Genbank Acc. No. AY090555 and AY090558) (Fauquet et al., 2003).Concluded that Sidaacuta are new hosts of Tomato yellow leaf curl Tanzania virus. An extensive search for yet undiscovered weed hosts is advocated, while the practice of farm sanitation is encouraged to eliminate reservoirs of the virus and vector (Kashina et al., 2003).

\section{Materials and Methods}

During a surveillance made continuously for two consecutive years (2019 and 2020), the weed Malvastrum coromendalianum and Sidaacuta is reported with severe infection of vein clearing virus and the other weeds nearby is not infected by this virus even with the vector; whitefly population and this is documented here for further research and to have a check on this weed in vegetable growing areas. Interestingly this virus may also be host specific as most of the other counterpart weeds expressed resistance to this virus and was documented earlier as Malvastrum yellow vein virus in china (ZHOU Xueping et al., 2003).This occurrence is more in Tamil Nadu, Madurai.

\section{Results and Discussion}

Under neem tree, weeds namely Sida acuta, Malvastrum coromandelianum, Ruella prostrata, Commelina benghalensis, Abuitlon indicum, Hibiscus micranthus, Aervalanata, Acalypha indica and Mellingtonis hortensis (tree seedlings aged 2 years) are observed in Agricultural College and Research Institute, Madurai. Among these weeds, the severe infection of vein clearing is found only in Malvastrum coromandelianum, Sidaacuta weed. Virus isolate Y47 was obtained from Malvastrum coromandelianum showing yellow vein symptom in Honghe, Yunnan Province. The complete nucleotide sequence of DNA-A was determined, it contains 2731 nucleotides, having typical genomic organization of a begomovirus, encoding 6 ORFs with 2 ORFs [AV1(CP) and AV2] in virion sense DNA and 4 ORFs (AC1 - AC4) in complementary sense DNA. Comparisons show that the total DNA-A of Y47 has the highest sequence identity (77\%) with that of Okra yellow vein mosaic virus-[201] (AJ002451), while less than $76 \%$ identities are found when compared with other begomoviruses. The molecular data show that virus isolate $\mathrm{Y} 47$ is a distinct begomovirus species, for which the name Malvastrum yellow vein virus is proposed. Satellite DNA molecule (Y47 $\beta$ ) was found to be associated with Y47 using the primers (beta01 and beta02) specific for DNA $\beta$. Y47 $\beta$ consists of 1348 nucleotides, with a functional ORF (C1) in complementary-sense DNA. Y47 $\beta$ has $62 \%-67 \%$ sequence identity with DNA $\beta$ molecule associated with Cotton leaf curl Multan virus or Cotton leaf curl Rajasthan virus, while lower than $46 \%$ sequence identities are found when compared with other reported DNA $\beta$ molecules. Relationship dendrograms show that DNA $\beta$ molecules are co-evolved with their help begomoviruses (ZHOU Xueping et al., 2003). Further, it was confirmed that Sida acuta are highly susceptible for vein clearing and also leaf curl virus of tomato which was reported earlier (Kashina et al., 2003). This infection is observed during October month in these volunteer plants continuously for the two years $(2019 \& 2020)$. 
Fig.1 Vein clearing in Sida acuta

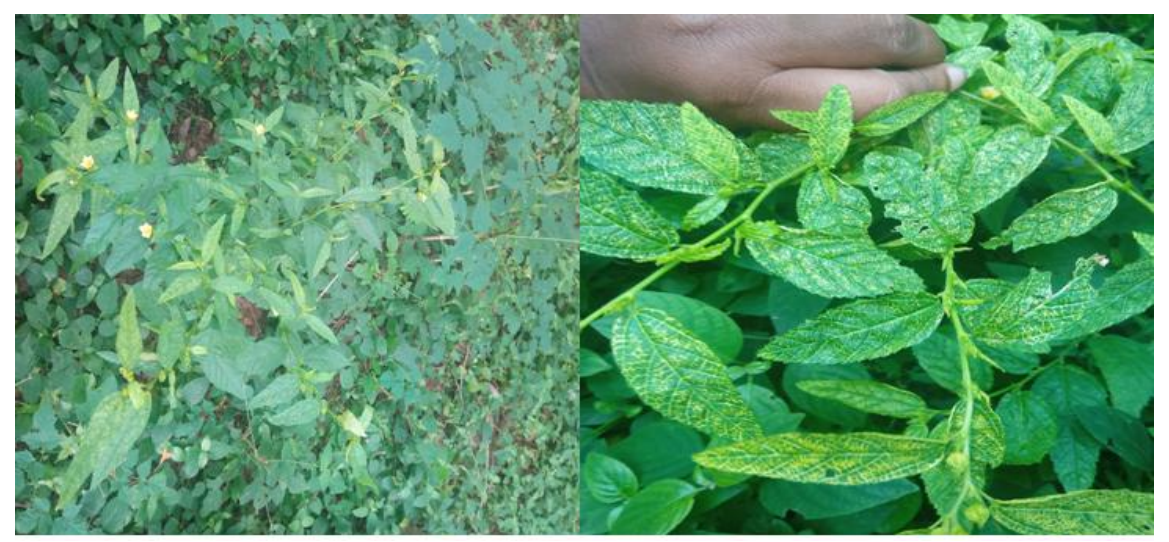

Fig.2 Vein clearing in Malvastrum coromandelianum

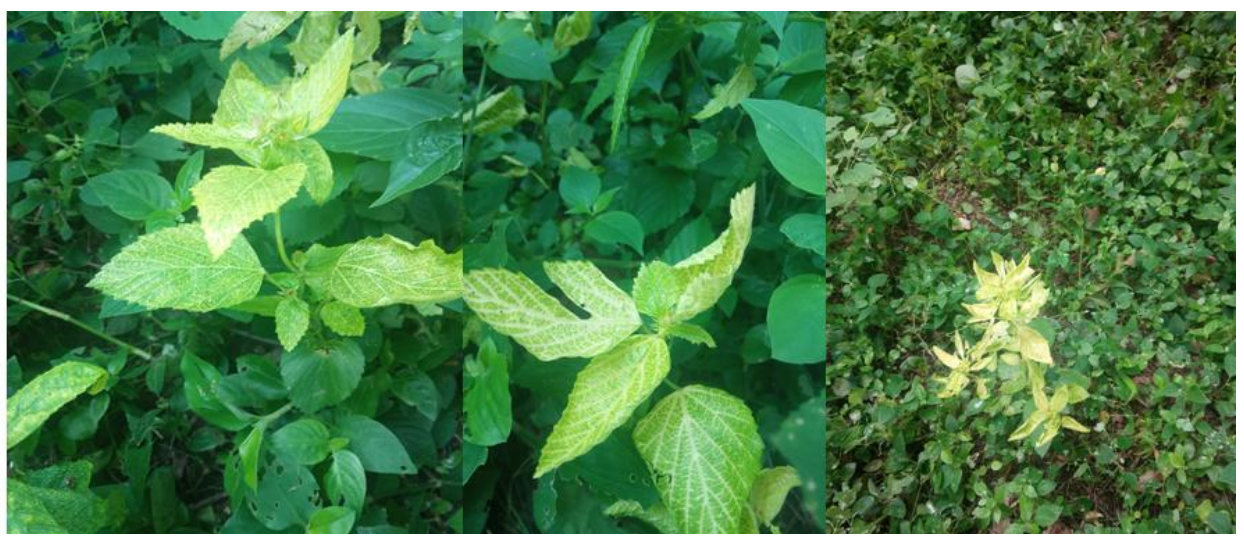

The population of the vector whitefly is also observed in the infected plant, this may facilitate for the transmission of the virus and Even though, with vector population, this Malvastrum coromandelianum (already reported as Malvastrum Yellow vein virus) and Sidaacuta is alone being observed with virus remaining weeds are not infected hence this may even host specific. Hence Malvastrum coromendalianum is documented as highly susceptible to this specific virus. The infected plants are with flowers and expressed with mild to severe symptoms. Hence in the vegetable growing areas, this weed might be under check and spread may be controlled if it transfers to crops. Recently, Subhashree Desikan, 2020 fromNational Centre of Biological Sciences (NCBS-TIFR), Bengaluru, has also discovered the virus called Synedrella Yellow Vein Clearing Virus and the virus was isolated by the researchers from a plant named Synedrella nodiflora, and it was able to infect tobacco and tomato plant in their studies. This virus is a representative of the Begomovirus family of viruses. "Begomoviruses are a large family with about 400 members and cause economic loss.

\section{References}

Fauquet CM, Bisaro DM, Briddon RW, Brown JK, Harrison BD, Rybicki EP, Stenger DC, Stanley J (2003) Revision of taxonomic criteria for species demarcation in the family Geminiviridae, and an updated list of begomovirus species. Archives of Virology 148: 405-421. 
Frischmuth T, Engel M, Lauster S, Jeske H. (1997). Nucleotide sequence evidence for the occurrence of three distinct whitefly-transmitted, sida-infecting bipartite geminiviruses in Central America. Journal of General Virology 78: 2675-2682

Hfer P, Engel M, Jeske H, Frischmuth T (1997) Host range limitation of a pseudo recombinant virus produced by two distinct bipartite geminiviruses. Molecular Plant-Microbe Interactions 10: 1019-1022

Kashina, B. \& MABAGALA, B. \&Mpunami, Anatolia. (2003). First Report of
Ageratum conyzoides L. and Sida acuta Burm F. as New Weed Hosts of Tomato Yellow Leaf Curl. Plant Prot. Sci.. 39. 10.17221/3822-PPS.

Subhashree Desikan, (2020). Biological plantvirus 'arms race' uncovered. The Hindu dated 11.10.2020

Zhou Xueping, XIE Yan, Peng Yan \& Zhang Zhongkai, (2003). Malvastrum yellow vein virus, a new Begomovirus species associated with satellite DNA molecule, Chinese Science Bulletin 48 (20): 2205 - 2209

\section{How to cite this article:}

Kalaichelvi, K. 2020. Report on Incidence of Malvastrum coromandelianum to Vein Clearing Virus Disease (Malvastrum Yellow Vein Virus Disease) in Madurai. Int.J.Curr.Microbiol.App.Sci. 9(11): 3743-3746. doi: https://doi.org/10.20546/ijcmas.2020.911.448 